Original Article

\title{
Yersinia massiliensis (Enterobacteriales: Enterobacteriaceae) in the host Anaphes nitens (Hymenoptera: Mymaridae): first report of association with insects
}

\author{
Yersinia massiliensis (Enterobacteriales: Enterobacteriaceae) no hospedeiro \\ Anaphes nitens (Hymenoptera: Mymaridae): primeiro relato de associação com insetos \\ M. F. Ribeiro ${ }^{a *}$ (D), V. R. Carvalho (iD, A. L. Favoreto ${ }^{a}$ (D), B. R. De Marchib (D), C. Jordana (iD, J. C. Zanuncio (iD), \\ M. A. Soares ${ }^{\text {(ID) A. J. V. Zanuncio }}$ (iD) and C. F. Wilcken ${ }^{\text {a }}$ (iD \\ aUniversidade Estadual Paulista - UNESP, Faculdade de Ciências Agronômicas, Departamento de Proteção Vegetal, Botucatu, SP, Brasil \\ bUniversity of Florida, Gulf Coast Research and Education Center, Wimauma, FL, USA \\ 'Universidade Federal de Viçosa - UFV, Departamento de Entomologia/BIOAGRO, Viçosa, MG, Brasil \\ dUniversidade Federal dos Vales do Jequitinhonha e Mucuri - UFVJM, Programa de Pós-graduação em Produção Vegetal, Diamantina, MG, Brasil \\ eUniversidade Federal de Viçosa - UFV, Departamento de Engenharia Florestal, Viçosa, MG, Brasil
}

\begin{abstract}
Endosymbiont bacteria can affect biological parameters and reduce the effectiveness of natural enemies in controlling the target insect. The objective of this work was to identify endosymbiont bacteria in Anaphes nitens (Girault, 1928) (Hymenoptera: Mymaridae), the main natural enemy used to manage Gonipterus platensis (Marelli, 1926) (Coleoptera: Curculionidae). Genomic DNA from six A. nitens populations was extracted and polymerase chain reactions ( $P C R$ ) were performed with the primers to detect endosymbiont bacteria in this insect. The PCR products were amplified, sequenced, and compared with sequences deposited in the GenBank for the bacteria identification. All A. nitens populations had the bacterium Yersinia massiliensis (Enterobacteriales: Enterobacteriaceae). This bacterium was originally described as free-living, and it is associated with and composes part of the A. nitens microbiota. This is the first report of $Y$. massiliensis in an insect host.
\end{abstract}

Keywords: biological control, egg parasitoid, microbiota, molecular entomology.

\begin{abstract}
Resumo
As bactérias endossimbiontes podem afetar os parâmetros biológicos e reduzirem a eficácia de inimigos naturais no controle do inseto alvo. $\mathrm{O}$ objetivo deste trabalho foi identificar bactérias endossimbiontes em Anaphes nitens (Girault, 1928) (Hymenoptera: Mymaridae), o principal inimigo natural usado no manejo de Gonipterus platensis (Marelli, 1926) (Coleoptera: Curculionidae). O DNA genômico de seis populações de A. nitens foi extraído e as reações em cadeia da polimerase (PCR) realizadas com os primers para detectar bactérias endossimbiontes neste inseto. Os produtos de PCR foram amplificados, sequenciados e comparados com as sequências depositadas no GenBank para identificação das bactérias. Todas as populações de A. nitens tinham a bactéria Yersinia massiliensis (Enterobacteriales: Enterobacteriaceae). Esta bactéria foi originalmente descrita como de vida livre e está associada e compõe parte da microbiota de A. nitens. Este é o primeiro relato de $Y$. massiliensis em um hospedeiro.
\end{abstract}

Palavras-chave: controle biológico, parasitoide de ovo, microbiota, entomologia molecular.

\section{Introduction}

The use of the egg parasitoid Anaphes nitens (Girault, 1928) (Hymenoptera: Mymaridae) is the main management strategy for the Eucalyptus spp. defoliator beetle, Gonipterus platensis (Marelli, 1926) (Coleoptera: Curculionidae) (Souza et al., 2016). This parasitoid is originally from Australia (Mapondera et al., 2012), and it has been successfully introduced in South Africa, Spain and California (United States of America) (Cordero-Rivera et al., 1999; Hanks et al., 2000) but with low efficiency in some

regions of Portugal, Chile and Brazil (Reis et al., 2012; Gumovsky et al., 2015; Souza et al., 2016). The reasons for the low parasitism rates in these countries are not fully understood and some authors attribute it to the seasons, altitude or host-parasitoid incompatibility (Reis et al., 2012; Mapondera et al., 2012).

Secondary endosymbiont bacteria can reduce fitness (Zug and Hammerstein, 2018) and parasitism rates (Furihata et al., 2015), increase susceptibility to 
hyperparasitoids (Van Nouhuys et al., 2016) and alter the structure and composition of parasitoid communities (Rothacher et al., 2016; Monticelli et al., 2019). It is important to know the host microbiota to evaluate its interference in parasitoid efficiency in biological control programs (Almeida et al., 2010). However, there are no reports of endosymbiont bacteria in $A$. nitens.

The objective of this work was to identify the presence of endosymbiont bacteria in the A. nitens host populations in Brazil.

\section{Materials and Methods}

Egg masses of $G$. platensis were collected in commercial Eucalyptus spp. plantations in the municipalities of Botucatu, Itararé, Itatinga, Lençóis Paulista and Pratânia in the state of São Paulo and Aracruz in the state of Espírito Santo, Brazil. They were kept in acrylic plates $(5 \mathrm{~cm}$ diameter and $1 \mathrm{~cm}$ high) in biochemical oxygen demand (BOD) incubator chamber at $25^{\circ} \mathrm{C}$ and a photoperiod of 12 hours until the emergence of $A$. nitens adults. The emerged insects were collected and preserved at $4{ }^{\circ} \mathrm{C}$.

Genomic DNA from 50 adult insects per $A$. nitens population was extracted following the Chelex 100 protocol (Walsh et al., 1991). These insects were washed in $70 \%$ alcohol, macerated and homogenized in a solution of $80 \mu \mathrm{L}$ of Chelex 100 resin (Bio-Rad Laboratories, USA) $10 \%$ and $8 \mu \mathrm{L}$ of proteinase $\mathrm{K}(20 \mu \mathrm{g} / \mathrm{mL})$ (Bioline, USA). Samples containing the DNA of the A. nitens populations were transferred to an Infinigen Thermal Cycler (model TC-96CG) and incubated at $95{ }^{\circ} \mathrm{C}$ for 20 minutes.

Egg capsules of $G$. platensis from laboratory rearing, up to 24 hours old and free of parasitism, were analyzed as the control. These capsules were immersed in distilled water for 1 hour, with a subsequent sampling of 35 eggs and the excrement layer of five egg capsules. The genomic DNA extraction procedure was the same as for $A$. nitens samples.

The $23 \mathrm{~S}$ region was amplified with the primers of the secondary endosymbiont Arsenophonus, with polymerase chain reaction (PCR) 5'-CGTTTGATGAATTCATAGTCAAA-3 '(Forward) and 5' GGTCCTCCAGTTAGTGTTACCCAAC-3 '(Reverse) (Thao and Baumann, 2004). A PCR mix containing $12.5 \mu \mathrm{L}$ of Taq DNA Polymerase (NeoBio), $7.5 \mu \mathrm{L}$ water milliQ $1.0 \mu \mathrm{L}$ of each primer and 3.0 $\mu \mathrm{L}$ of DNA, totaling a volume of $25 \mu \mathrm{L}$, was used in each of the population samples. PCR reactions were performed under the following conditions: initial denaturation temperature at $95^{\circ} \mathrm{C}$ for $2 \mathrm{~min}$, followed by 30 cycles each of $95^{\circ} \mathrm{C}$ for $30 \mathrm{sec}, 58^{\circ} \mathrm{C}$ for $30 \mathrm{sec}, 72^{\circ} \mathrm{C}$ for $1 \mathrm{~min}$. and a final extension of $72^{\circ} \mathrm{C}$ for $5 \mathrm{~min}$. A molecular marker $100 \mathrm{pb}$ (Norgen) and $1 \%$ agarose gel, visualized in a UV Light Transilluminator (Major Science), were used.

PCR products were purified using a "PCR Purification Kit" (Cellco Biotec, Brazil). The amplified DNA fragments of the bacteria were sequenced by the Sanger DNA Automatic Sequencer (Model: ABI 3500-Applied Biosystems), at the Institute of Biotechnology (IBTEC/UNESP) in Botucatu and compared with the sequences deposited in GenBank, using the BLASTn program (Blast, 2020).
The nucleotide sequences obtained were analyzed using the software Geneious v11.1.5 and compared to a dataset composed of other accessions retrieved from the GenBank. The sequences were aligned using MAFFT v7.222 within the Geneious v.11.1.5 software, and phylogenetic analysis was performed using MrBayes 3.2.2 (Ronquist and Huelsenbeck, 2003). Two independent runs were conducted simultaneously using 10 million generations and excluding 25\% from the resulting tree as burning. Phylogenetic tree was visualized, edited and rooted using FigTree v1.4.4 (FigTree, 2020).

\section{Results}

BLASTN analysis of the $600 \mathrm{bp}$ amplicon resulted in high identity (98\% identity with the accession number CP028487-1) with the bacterium Yersinia massiliensis (Enterobacteriales: Enterobacteriaceae).

This bacterium was found in all $A$. nitens populations and it was absent in G. platensis eggs and excrement layer of the egg capsules (Figure 1). Phylogenetic analysis grouped the sequences of this bacterium in a single sub-clade including samples from all localities (Figure 2).

\section{Discussion}

The presence of the bacterium $Y$. massiliensis in all populations of $A$. nitens includes it in the composition of the microbiota of this insect host. The Y. massiliensis DNA sequencing from the primer developed for the endosymbiont Arsenophonus may be due to the amplification of the 23S gene region in a non-specific way (Rekha et al., 2006). Yersinia massiliensis was

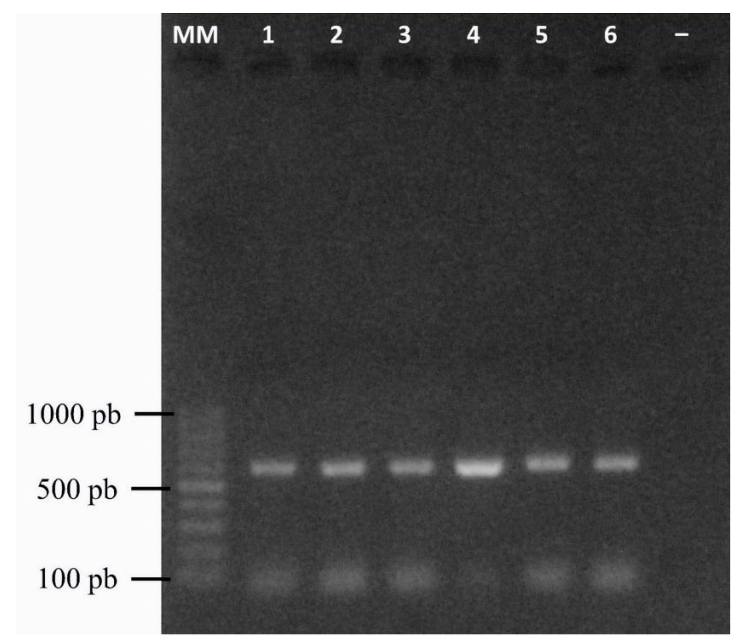

Figure 1. Agarose gel with polymerase chain reaction (PCR) products for Yersinia massiliensis (Enterobacteriales: Enterobacteriaceae) in individuals of different Anaphes nitens (Hymenoptera: Mymaridae) host populations. $\mathrm{MM}=$ molecular marker; $1=$ population of Aracruz, Espírito Santo, Brazil; 2= population of Botucatu, São Paulo, Brazil; 3= population of Itatinga, São Paulo, Brazil; 4= population of Lençóis Paulista, São Paulo, Brazil; 5= population of Pratânia, São Paulo, Brazil; 6= population of Itararé, São Paulo, Brazil. 


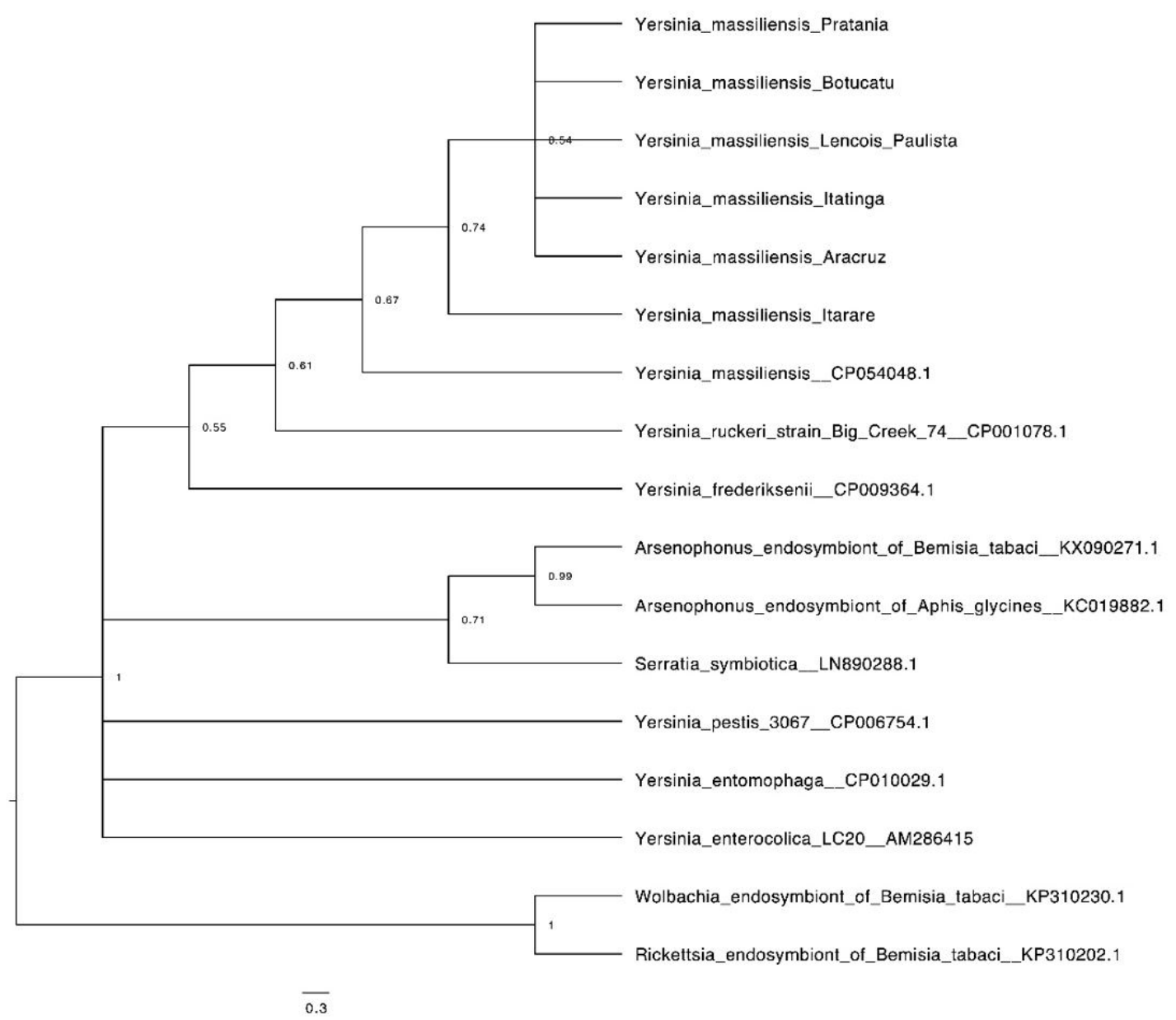

Figure 2. Phylogenetic analysis for Yersinia massiliensis symbiont samples from different Anaphes nitens populations (Hymenoptera: Mymaridae).

originally described as a freshwater free-living gramnegative coccobacillus (Merhej et al., 2008) and has been found in aquatic and food environments in Brazil and Argentina (Souza et al., 2011) as non-pathogenic (Thomas et al., 2018).

Some bacteria in the Enterobacteriaceae family may be free-living bacteria or secondary endosymbionts (Renoz et al., 2019), as the genus Hamiltonella, Regiella, Serratia and Yersinia (Kikuchi, 2009). The composition of the insect microbiota varies with the host, from a few dozens in Lepidoptera (Paniagua Voirol et al., 2018) to hundreds of species in termites (Brune and Dietrich, 2015). Insects can acquire free-living bacteria and may establish mutual relations with them (Sudakaran et al., 2017). The host diet is the main impact factor in the available resources for the microbiota and, consequently, defines the microorganism species surviving in its interior (Foster et al., 2017).

The genus Yersinia currently contains 15 species, Y. enterocolica, Y. pseudotuberculosis and Y. pestis are pathogenic to humans and some vertebrates, $Y$. entomophaga is pathogenic to insects, and the others are considered non-pathogenic opportunistic bacteria
(Merhej et al., 2008; Hurst et al., 2011; Souza et al., 2011, Reuter et al., 2014). Yersinia massiliensis was found in A. nitens collected in areas with a high parasitism rate (State of Espirito Santo) or low parasitism rate (State of São Paulo) (Souza et al., 2016) by this natural enemy on G. platensis. Therefore, it is unlikely to be the cause of parasitism differences in Brazil.

Endosymbiont bacteria interactions should be studied case by case, as may range from positive to negative depending on the host, as observed by Wolbachia, which increased parasitism of Asobara japonica Belokobylskij (Hymenoptera: Braconidae) but reduced fecundity of Leptopilina heterotoma Thomson (Hymenoptera: Figitidae) (Fleury et al., 2000; Furihata et al., 2015). In Trichogramma atopovirilia (Hymenoptera: Trichogrammatidae), Wolbachia induce parthenogenesis and its infection does not show negative effects (Almeida et al., 2010; Almeida and Stouthamer, 2017).

The association of $Y$. massiliensis with the parasitoid A. nitens represents the first report of this bacterium in an insect host. 


\section{Acknowledgements}

To the Brazilian institutions "Conselho Nacional de Desenvolvimento Científico e Tecnológico (CNPq)", "Coordenação de Aperfeiçoamento de Pessoal de Nível Superior (CAPES- Finance Code 001), "Fundação de Amparo à Pesquisa do Estado de Minas Gerais (FAPEMIG)" and "Programa Cooperativo sobre Proteção Florestal/PROTEF do Instituto de Pesquisas e Estudos Florestais/IPEF" for financial support. David Michael Miller, a professional editor and proofreader and a native English speaker has reviewed and edited this article for grammar, punctuation, spelling, structure, word choice, and readability.

\section{References}

ALMEIDA, R.P. and STOUTHAMER, R., 2017. Phylogeny of the Trichogramma endosymbiont Wolbachia, an alphaproteobacteria (Rickettsiae). Brazilian Journal of Biology = Revista Brasileira de Biologia, vol. 78, no. 3, pp. 421-428. http://dx.doi. org/10.1590/1519-6984.166671. PMid:29160361.

ALMEIDA, R.P., VAN LENTEREN, J.C. and STOUTHAMER, R., 2010. Does Wolbachia infection affect Trichogramma atopovirilia behaviour? Brazilian Journal of Biology = Revista Brasileira de Biologia, vol. 70, no. 2, pp. 435-442. http://dx.doi.org/10.1590/ S1519-69842010005000016. PMid:20379652.

BLAST - Basic local alignment search tool. 2020. [viewed 4 April 2019]. Available from: https://blast.ncbi.nlm.nih.gov/Blast.cgi.

BRUNE, A. and DIETRICH, C., 2015. The gut microbiota of termites: digesting the diversity in the light of ecology and evolution. Annual Review of Microbiology, vol. 69, no. 1, pp. 145-166. http://dx.doi.org/10.1146/annurev-micro-092412-155715. PMid:26195303.

CORDERO-RIVERA, A., SANTOLAMAZZA-CARBONE, S. and ANDRÉS, J.A., 1999. Life cycle and biological control of the Eucalyptus snout beetle (Coleoptera, Curculionidae) by Anaphes nitens (Hymenoptera, Mymaridae) in north-west Spain. Agricultural and Forest Entomology, vol. 1, no. 2, pp. 103-109. http://dx.doi. org/10.1046/j.1461-9563.1999.00016.x.

FLEURY, F., VAVRE, F., RIS, N., FOUILLET, P. and BOULÉTREAU, M., 2000. Physiological cost induced by the maternally-transmitted endosymbiont Wolbachia in the Drosophila parasitoid Leptopilina heterotoma. Parasitology, vol. 121, no. 5, pp. 493-500. http:// dx.doi.org/10.1017/S0031182099006599. PMid:11128800.

FIGTREE - Molecular Evolution, Phylogenetics and Epidemiology. 2020. [viewed 20 May 2019]. Available from: http://tree.bio.ed.ac.uk/software/figtree/.

FOSTER, K.R., SCHLUTER, J., COYTE, K.Z. and RAKOFF-NAHOUM, S. 2017. The evolution of the host microbiome as an ecosystem on a leash. Nature, vol. 548, no. 7665, pp. 43-51. http://dx.doi. org/10.1038/nature23292. PMid:28770836.

FURIHATA, S., HIRATA, M., MATSUMOTO, H. and HAYAKAWA, Y., 2015. Bacteria endosymbiont, Wolbachia, promotes parasitism of the parasitoid wasp Asobara japonica. PLoS ONE, vol. 10, no. 10, pp. e0140914. http://dx.doi.org/10.1371/journal.pone.0140914. PMid:26492411.

GUMOVSKY, A., LITTLE, D., ROTHMANN, S., JAQUES, L. and MAYORGA, S.E., 2015. Re-description and first host and biology records of Entedon magnificus (Girault \& Dodd) (Hymenoptera, Eulophidae), a natural enemy of Gonipterus weevils (Coleoptera, Curculionidae), a pest of Eucalyptus trees. Zootaxa, vol. 3957, no. 5, pp. 577-584. http://dx.doi.org/10.11646/zootaxa.3957.5.6. PMid:26249097.
HANKS, L.M., MILLAR, J.G., PAINE, T.D. and CAMPBELL, C.D., 2000. Classical biological control of the Australian weevil Gonipterus scutellatus (Coleoptera: Curculionidae) in California. Environmental Entomology, vol. 29, no. 2, pp. 369-375. http:// dx.doi.org/10.1093/ee/29.2.369.

HURST, M.R., BECHER, S.A., YOUNG, S.D., NELSON, T.L. and GLARE, T.R., 2011. Yersinia entomophaga sp. nov., isolated from the New Zealand grass grub Costelytra zealandica. International Journal of Systematic and Evolutionary Microbiology, vol. 61, no. 4, pp. 844849. http://dx.doi.org/10.1099/ijs.0.024406-0. PMid:20495033.

KIKUCHI, Y., 2009. Endosymbiotic bacteria in insects: their diversity and culturability. Microbes and Environments, vol. 24, no. 3, pp. 195-204. http://dx.doi.org/10.1264/jsme2.ME09140S. PMid:21566374.

MAPONDERA, T.S., BURGESS, T., MATSUKI, M. and OBERPRIELER, R.G., 2012. Identification and molecular phylogenetics of the cryptic species of the Gonipterus scutellatus complex (Coleoptera: Curculionidae: Gonipterini). Australian Journal of Entomology, vol. 51, no. 3, pp. 175-188. http://dx.doi.org/10.1111/j.14406055.2011.00853.x.

MERHEJ, V., ADÉKAMBI, T., PAGNIER, I., RAOULT, D. and DRANCOURT, M., 2008. Yersinia massiliensis sp. nov., isolated from fresh water. International Journal of Systematic and Evolutionary Microbiology, vol. 58, no. 4, pp. 779-784. http://dx.doi.org/10.1099/ijs.0.652190. PMid:18398169.

MONTICELLI, L.S., OUTREMAN, Y., FRAGO, E. and DESNEUX, N., 2019. Impact of host endosymbionts on parasitoid host rangefrom mechanisms to communities. Current Opinion in Insect Science, vol. 32, no. 1, pp. 77-82. http://dx.doi.org/10.1016/j. cois.2018.11.005. PMid:31113635.

PANIAGUA VOIROL, L.R., FRAGO, E., KALTENPOTH, M., HILKER, M. and FATOUROS, N.E., 2018. Bacterial symbionts in Lepidoptera: their diversity, transmission, and impact on the host. Frontiers in Microbiology, vol. 9, pp. 556. http://dx.doi.org/10.3389/ fmicb.2018.00556. PMid:29636736.

REIS, A.R., FERREIRA, L., TOMÉ, M., ARAUJO, C. and BRANCO, M., 2012. Efficiency of biological control of Gonipterus platensis (Coleoptera: Curculionidae) by Anaphes nitens (Hymenoptera: Mymaridae) in cold areas of the Iberian Peninsula: Implications for defoliation and wood production in Eucalyptus globulus. Forest Ecology and Management, vol. 270, pp. 216-222. http:// dx.doi.org/10.1016/j.foreco.2012.01.038.

REKHA, R., RIZVI, M.A. and JAISHREE, P., 2006. Designing and validation of genus-specific primers for human gut flora study. Electronic Journal of Biotechnology, vol. 9, no. 5, pp. 1. http:// dx.doi.org/10.2225/vol9-issue5-fulltext-2.

RENOZ, F., PONS, I., VANDERPOORTEN, A., BATAILLE, G., NOEL, C., FORAY, V., PIERSON, V. and HANCE, T., 2019. Evidence for hutassociated Serratia symbiotica in wild aphids and ants provides new perspectives on the evolution of bacterial mutualism in insects. Microbial Ecology, vol. 78, no. 1, pp. 159-169. http:// dx.doi.org/10.1007/s00248-018-1265-2. PMid:30276419.

REUTER, S., CONNOR, T.R., BARQUIST, L., WALKER, D., FELTWELL, T., HARRIS, S.R., FOOKES, M., HALL, M.E., PETTY, N.K., FUCHS, T.M., CORANDER, J., DUFOUR, M., RINGWOOD, T., SAVIN, C., BOUCHIER, C., MARTIN, L., MIETTINEN, M., SHUBIN, M., RIEHM, J.M., LAUKKANEN-NINIOS, R., SIHVONEN, L.M., SIITONEN, A., SKURNIK, M., FALCÃO, J.P., FUKUSHIMA, H., SCHOLZ, H.C., PRENTICE, M.B., WREN, B.W., PARKHILL, J., CARNIEL, E., ACHTMAN, M., MCNALLY, A. and THOMSON, N.R., 2014. Parallel independent evolution of pathogenicity within the genus Yersinia. Proceedings of the National Academy of Sciences of the United States of America, vol. 111, no. 18, pp. 6768-6773. http://dx.doi.org/10.1073/pnas.1317161111. PMid:24753568. 
RONQUIST, F. and HUELSENBECK, J.P., 2003. MrBayes 3: bayesian phylogenetic inference under mixed models. Bioinformatics, vol. 19, no. 12, pp. 1572-1574. http://dx.doi.org/10.1093/ bioinformatics/btg180. PMid:12912839.

ROTHACHER, L., FERRER-SUAY, M. and VORBURGER, C., 2016 Bacterial endosymbionts protect aphids in the field and alter parasitoid community composition. Ecology, vol. 97, no. 7, pp. 1712-1723. http://dx.doi.org/10.1890/15-2022.1. PMid:27859175.

SOUZA, N.M., JUNQUEIRA, L.R., WILCKEN, C.F., SOLIMAN, E.P., CAMARGO, M.B., NICKELE, M.A. and BARBOSA, L.R., 2016. Ressurgência de uma antiga ameaça: Gorgulho-do-eucalipto Gonipterus platensis (Coleoptera: Curculionidae). Piracicaba: Instituto de Pesquisas e Estudos Florestais, 20 p. Circular Técnica, no. 209

SOUZA, R.A., FALCÃO, D.P. and FALCÃO, J.P., 2011. Emended description of Yersinia massiliensis. International Journal of Systematic and Evolutionary Microbiology, vol. 61, no. 5, pp. 10941097. http://dx.doi.org/10.1099/ijs.0.021840-0. PMid:20525812.

SUDAKARAN, S., KOST, C. and KALTENPOTH, M., 2017. Symbiont acquisition and replacement as a source of ecological innovation. Trends in Microbiology, vol. 25, no. 5, pp. 375-390. http://dx.doi. org/10.1016/j.tim.2017.02.014. PMid:28336178.
THAO, M.L. and BAUMANN, P., 2004. Evidence for multiple acquisition of Arsenophonus by whitefly species (Stenorrhyncha: aleyrodidae). Current Microbiology, vol. 48, no. 2, pp. 140-144. http://dx.doi.org/10.1007/s00284-003-4157-7. PMid:15057483.

THOMAS, M.C., ARLING, V., GOJI, N., JANZEN, T.W., DUCEPPE, M., MATHEWS, A., CARRILLO, C. and AMOAKO, K.K., 2018. First complete genome sequence of Yersinia massiliensis. Genome Announcements, vol. 6, no. 20, e00416-18. http://dx.doi. org/10.1128/genomeA.00416-18. PMid:29773629.

VAN NOUHUYS, S., KOHONEN, M. and DUPLOUY, A., 2016. Wolbachia increases the susceptibility of a parasitoid wasp to hyperparasitism. The Journal of Experimental Biology, vol. 219, no. 19, pp. 2984-2990. http://dx.doi.org/10.1242/jeb.140699. PMid:27707863.

WALSH, P., METZGER, D. and HIGUCHI, R., 1991. Chelex-100 as a medium for simple extraction of DNA for PCR-based typing from forensic material. BioTechniques, vol. 10, no. 4, pp. 506513. PMid: 1867860

ZUG, R. and HAMMERSTEIN, P., 2018. Evolution of reproductive parasites with direct fitness benefits. Heredity, vol. 120, no. 3, pp. 266-281. http://dx.doi.org/10.1038/s41437-017-0022-5. PMid:29234159. 